\title{
INNOVATIVE APPROACH TO THE CONCEPT OF INNOVATION IN PUBLIC ADMINISTRATION
}

\author{
Viera Papcunová* \\ Constantine the Philosopher University in Nitra, Slovakia, e-mail: vpapcunova@ukf.sk \\ Eva Balážová \\ Slovak University of Agriculture in Nitra, Slovakia, e-mail: eva.balazova@uniag.sk

\section{Radomíra Hornyák Gregáňová} \\ Slovak University of Agriculture in Nitra, Slovakia, e-mail: radomira.greganova@uniag.sk
}

Received October 2018; Accepted December 2018

\begin{abstract}
Purpose - Public administration, its functionality and efficiency become an important element of prosperity not only for individual economies but also for transnational entities. We are looking for new directions and new practices for public administration that are inspired by the business sector, which to orientation for results, satisfaction of customers, and reflections on the mix of services that will be provided to the citizen. The basic principle of all reforms in public administration is the understanding of administration as a service to citizens. The aim of the paper is to explain the essence of some selected innovative theoretical approaches in public administration and also to analyze citizens' access for e - government from the point of view of communication with representatives of the public administration at the level of individual EU member states.

Design/methodology/approach - Characteristics of selected innovative approaches in public administration. Based on selected indicators within EU member countries, to analyze citizens' access for e - government.

Findings - Innovative methods introduced in public administration are implied by the private sector. The availability of digital information of the public administration for citizens, about its representatives as well as about the financing of public administration has greatly improved over the period 2008-2017.

Research limitations/implications - The availability of citizens' information in the context of communication with the public administration was monitored on the basis of selected indicators within the EU member states over the period 2008-2017.

Practical implications - In addition to summarizing individual innovative approaches of management of public administration, the practical benefits are also experience with individual types of these approaches of management of public administration public administration in selected countries.

Originality/Value - Theoretical aspects are complemented by indicators that assess the use of e-government by citizens of EU Member States.

Keywords: public administration, management of public administration, innovative approaches, e- government, EU member's countries.

Research type literature review.

JEL classification: H40, H0, B40.
\end{abstract}

\footnotetext{
* Corresponding author.
} 


\section{Introduction}

In the past, innovations had been typical of the manufacturing business sector, where through innovation, businesses have sought to increase their competitiveness in the market and, at the same time, to innovate their production processes and products to increase their sales. In the context of public administration reform are starting to appear innovations also into the public administration. By introducing innovations in the process of providing services, public administration seeks, on the one hand, to bring citizens better services for them and, on the other, to more effectively manage allocated financial resources. In this article, we try to characterize selected innovative approaches to public administration and also evaluating the use of e - Government in individual EU member countries. For the analysis, we used the selected indicators which monitor National Statistical Institutes within the EU countries, and in the theoretical background to characterizing the theoretical aspects of selected innovative approaches to public administration.

The term "innovation" can be defined as a change in behavior in the broadest sense. The first most frequently mentioned of the innovation attribute is the change of status quo. It is important, however, not to exchange the innovate with the concept of change, since change is typical for most organizations, but innovation is about implementing of new knowledge or performing new tasks. Another fundamental attribute is the change of quality. So the output of the change must be qualitatively observable. And the no less important attribute of innovation is a deliberate change. Innovations in the public sector can be present by the system changes, reforms, restructuring, and reorganization and so on (Staroňová et al., 2010).

The management of public administration institutions is divergence from the management of private companies, due mainly to the specific position of public administration and the fact that its services are not provided on a market-based basis. The political exposure of the main activities in turn brings many characteristics that relate to staffing in individual public administration institutions and are also triggered by the force of other laws governing employment in public administration institutions (Wright, Nemec, 2003). Nobody doubts that many innovations in public organizations have been inspiration from the private sector. There are many cases where a method was first used in the private sector and only then introduced in the public sector for instance PPBS (Planning, Programming and Budgeting), ZBB (Zero - Based Budgeting), zero-budgeting, TQM (Total Quality Management) and many others. Most of these methods persist in the public sector today, but many have already been replaced by new methods for instance New Public Management. That is why the core elements of management activities in the two sectors are the same. Hrašková (2011) notes that public administration differs from corporate management in that it assures the economic aspect of the right processes within the organization and, on the other hand, contributes 
to the functional analysis of politics and the economy in the external environment, in the state, in the municipality, in the region, or in the sector. Through its activity it helps to strengthen the state discipline, applies appropriate support to entrepreneurial subjects and develops self-government. From a socio-political point of view, it explores the responses to public administration through marketing, applies the principles of social and material support, health care and develops opportunities for providing better services to the population (Országhová, 2017). Vanagas and Juškys (2017) note that the conflict between public and private interest occurs when in a certain situation this private interest has direct or indirect impact on the performed official duties.

The specific management of regions, cities and municipalities, which are represent selfgovernment, are understanding as a division of classical management. Unlike the business sector, where individual decisions can be made, in public administration, individual citizens' decisions must be transformed into a single collective decision for instance about the amount of funds provided for health care, for education, especially through elected representatives. One of the restrictions of planning, that belong to the most important managerial functions is that public administration is governed by laws, regulations, directives and generally binding regulations.

\section{Theoretical background}

The socio-economic development of the country depends directly on the innovative technological potential and on the effectiveness of the state's stimulation of its development at all levels of the national economy. The state, in all available ways, should encourage economic actors to develop and implement innovations, thereby creating favorable conditions for innovative and technological development of production. This behavior will also strengthen the position of public authorities. So, the socio-economic development of the country depends directly on the innovationtechnological potential and on the efficiency of public administration in its development at all levels of the economy (Dudchenko and Vitman, 2018). The public administration system according to Hamalová et al. (2014), can be seen in two ways: 1) Public administration - corresponds to the traditional understanding of the public administration as a system of bodies providing the executive function of state, principles and practices applied by the state administration (Výrostová, 2017). The administrative understanding of the public administration corresponded to its real status and influence in the administrative types of the state, which had been characteristic for the European states since the 16th century (the emergence of the administrative state in France) until the second half of the 20th century, 2) Public management - public administration fulfills its constitutional role, managers are responsibly accountable and creatively responding to changes in society in accordance with legal constraints. It can be defined as a set of laws, regulations, judgments and 
administrative procedures that restrict, but at the same time enable the exercise of public power in the public interest (Lynn, 2001).

The public decision-making process seeks the means to more effectively manage the public administration and also to use the endogenous resources more economically. One option is to introduce new approaches to governance.

Subsequently, after 1980 a new wave of reform of public administration which to be called New Public Management. Schick (1999) note that the base prerequisites for the application of New Public Management in practice are that the managers have set clear goals with measurable indicators and they are flexible and responsible when using resources. Also the central authorities transfer the tasks to the regional level and then to the local level and the government rather checks the results as the procedures for achieving the objectives. New Public Management is not an integrated and coherent theory, but rather a free collection of different doctrines, principles and measures that are partly in opposition to one another. The forms and objectives of the New Public Management may also vary. In the UK, the goal of the New Public Management was to create a minimalist state. In Norway, it wanted to protect the state. In Australia, at the outset, it focused only on the management of public enterprises (Bevir et al., 2003). At the end of the 1990s, New Public Management began to lose its decisive position. One of the reasons was the insufficient standing of a citizen in the performance of public administration. Lacina (2012) points to Gray and Jenkins statement that New Public Management is complicated, incomplete, paradoxical and displays signs of intellectual incoherence. As a result of such criticism of New public Management to create a new concept of public administration - Good Governance. Methods of public governance as privatization of state services and decentralization of state governance lay the groundwork for the transition from bureaucracy to cooperation in mutual work (Beresecká, 2017, Hudáková, 2016)

Much more interesting and perspective is a direction of model of Good Governance - the involvement of society into management (Danshina and Britchenko, 2017). Castellanos (2017) also mentions some deficiencies of this concept. One of them was the abolition of the administrative authorities of the government. The creation of agencies dealing primarily with the political aspects of public administration has raised the problem of horizontal coordination and further responsibility. The reform from top to bottom has also been criticized. Policies derived from the New Public Management agenda have fallen from management levels and resources (such as citizens' knowledge of public issues or implicit state administration bodies) were unnecessary. Blind confidence in instruments of neoclassical economics when designing organizational structures, public policies, programs, etc. gave this approach more ideological than a scientific character. This points to the fact that good political communication and transparency are not always linked to the means available, it is also a question of political will. 
Information technology has become one of the base elements of managerial reform, and electronic government (e-government) may figure prominently in future governance (StasiakBetlejewska and Kováč, 2013, Mura et al. 2017). E-government is one of most interesting concepts introduced in the field of public administration in the late1990s, though it has not been clearly defined and under-stood among scholars and practitioners of public administration. Like many managerial concepts and practices in public administration (TQM, strategic management, participative management, etc.), the idea of e-government is based on private-sector adoption of so-called e-business and e - commerce. The Global Study of E-government, a recent joint research initiative for global e-government by the United Nations and the American Society for Public Administration to characterize of e-government as using of all information and communication technologies, from fax machines to wireless palm pilots, to facilitate the daily administration of government (Moon, 2002). To digitize of public institutions can lead both from central and local level, depending on a number of factors (size, centralization, management style, etc.). Some research studies support the idea that local governments are bad prepared to implement e-government services for a number of reasons. In Romanian city halls, which the majority of governmental services are provided by these institutions, their internal IT departments, which are tasked by default with digitizing public institutions, become congested. In Romania, central coordination of e- government is lacking. Despite having adopted digitalization strategies (both national and as part of the EU), the Romanian government failed to create and implement the necessary basic tools without which these plans cannot be put into practice. For example, Romania does not have a coherent strategy to introduce eIDs, national registries are incomplete and without common standards (so it means that some public institutions do not use them, relying instead on their own databases) and adopted a framework for interoperability only at the end of 2017, with implementation moving very slowly. (Urs, 2018). The problematic character of e-Government systems to summarized in South Africa Singh, Travica (2018) who note that the social context surrounding senior managers in charge of e-Government systems has also another face. Most apparently, there is a lack of information and communication policies and strategies in many organizations are missing. But on the other hand sometimes the senior managers demonstrated disregard for these policies, and openly encouraged others to forget about these policies. Even when certain information and communications policies existed, they were not updated, or adjusted to e-government systems. Ebbers, Jansenb, van Deursen (2016) to realize the research on a sample of 779 respondents aged 18-25 who completed the survey in the city of The Hague; one of the biggest cities of the Netherlands. From results of research show that thesis that when it comes to the uptake of e - government, at least in developed countries, digital skills become less relevant. However, they be important when it concerns the perceived quality, expressed in terms of 
satisfaction of citizens. This could mean that, in the long run, many citizens are going to use e government anyway, no matter how (un)skilled they are, no matter how complex these services are.

\section{Research methodology}

In EU Member States 28 every year is monitored number of citizens who communication with public administrations through internet. Data given in this domain are collected annually by the National Statistical Institutes and are based on Eurostat's annual model questionnaires on ICT (Information and Communication Technologies) usage in households and by individuals. The model questionnaire changes every year. The aim of the European ICT surveys is the timely provision of statistics on individuals and households on the use of Information and Communication Technologies at European level.

The aim of the paper is to explain the essence of some selected innovative theoretical approaches in public administration and also to analyze citizens' access for e - government from the point of view of communication with representatives of the public administration at the level of individual EU member states. In this context, we analyzed the following indicators:

- Individuals interacting online with public authorities, last 12 months - This indicator present individuals have used internet, in the last 12 months, for interaction with public authorities. It includes obtaining information from public authorities web sites, OR downloading official forms OR sending filled in forms.

- Individuals submitting completed forms to public authorities, over the internet, last 12 months - This indicator present two aspects:

1) Online Service Completion - share of the steps in a Public Service life event that can be completed online (Online availability sub-indicator for User centricity of the e Government benchmark)

2) Pre-filled forms - Amount of data that is pre-filled in Public Services' online forms (Authentic sources Key Enabler indicator of e - Government benchmark)

For both indicators present the population of individuals consists of all individuals aged 16 to 74. As part of the analysis of selected indicators, we evaluated the 2008-2017 time series as well as the 2008 and 2017 change index. 


\section{Result research}

In 2017 compared to 2008, the population of 16-74 years of age, who used the internet for the next 12 months to communicate with public administrations, average increased by $39 \%$ in all EU28 countries. From the point of view of individual Member States, there has been an increase of the number of citizens who communicating with the public administration electronically in all countries. The most significant increase of the number of these citizens are registered in Greece and Latvia (more than a 3 - fold increase) and more than a 2-fold increase we see in Estonia, Belgium, Lithuania, Czech Republic, Portugal, Croatia and Bulgaria (Figure 1, Table 1).

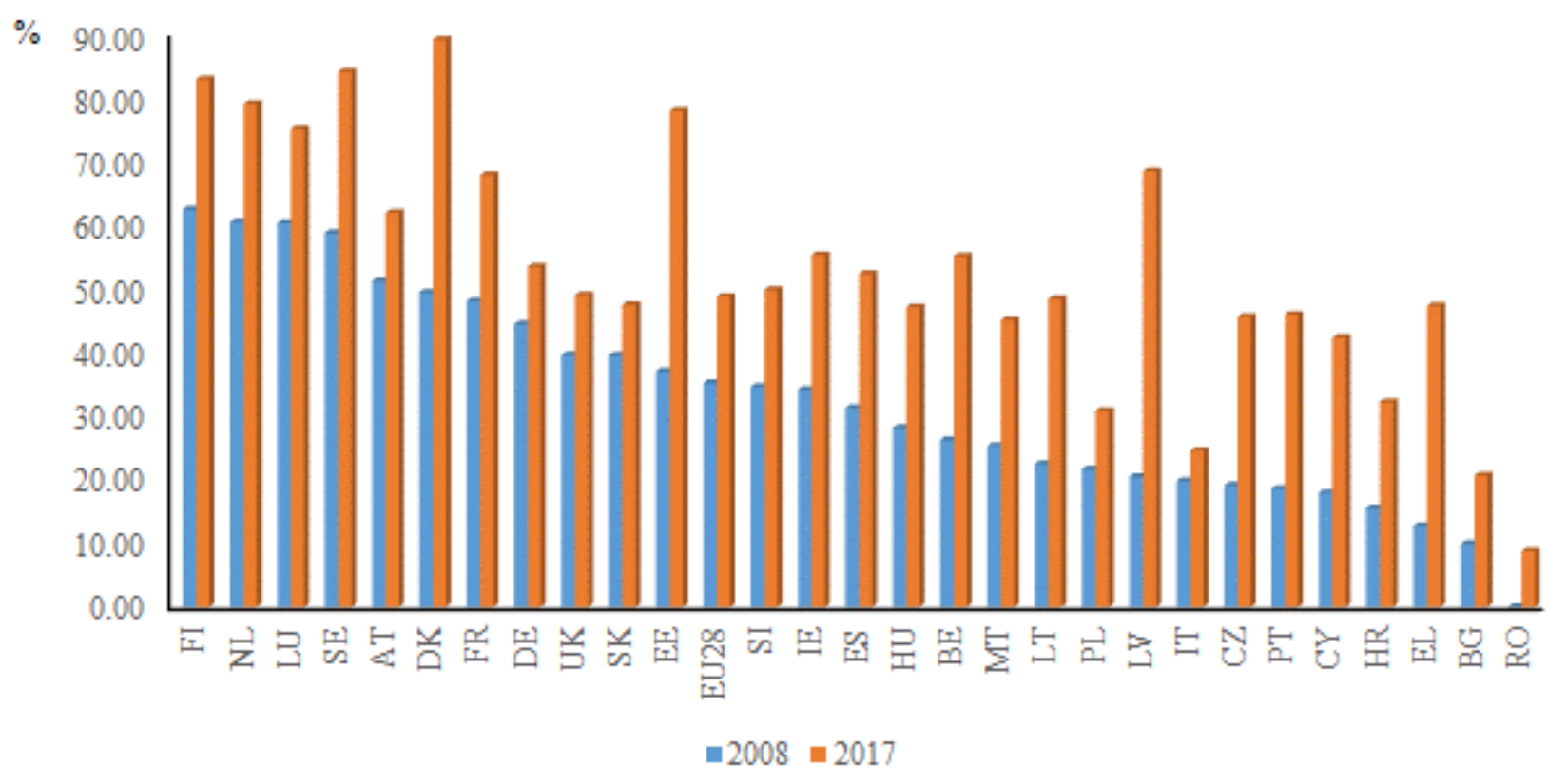

Source: According to European Commission, Digital Scoreboard, 2017

Figure 1. Individuals interacting online with public authorities, last 12 months

The increase of the electronic communication with public administration is mainly due to the massive introduction of electronization of public administration and with implementation of egovernment into public administration. The increase of the number of subjects of public administrations which provide their information through web pages is also confirmed by research Fernandez - Falero, Trabadela - Robles, Garces - Botacio, Ruano - Lopez (2017) who note that in Spain, the law of transparency is applicable, which provides access to public information. They carried out a study in 2015 and 2016 when they surveyed the websites of municipalities with a population of more than 7,000 and more than 10,000. The results of the research showed, that the availability of information about municipalities and their financial management was up by $12.5 \%$ year-on-year, as well as information about political representatives of municipalities $(11.3 \%)$. 
Table 1. Individuals interacting online with public authorities, last 12 months in EU 28 over the years 2007-2018 (\%)

\begin{tabular}{|c|c|c|c|c|c|c|c|c|c|c|c|c|}
\hline name & code & 2008 & 2009 & 2010 & 2011 & 2012 & 2013 & 2014 & 2015 & 2016 & 2017 & $\begin{array}{c}\text { Index } \\
\text { 2008/2017 }\end{array}$ \\
\hline Finland & FI & 62.49 & 64.20 & 67.54 & 68.03 & 69.57 & 69.35 & 80.18 & 78.57 & 81.61 & 82.97 & 1.33 \\
\hline Netherlands & NL & 60.54 & 61.03 & 63.64 & 62.34 & 66.82 & 78.51 & 75.34 & 74.89 & 76.10 & 79.12 & 1.31 \\
\hline Luxembourg & $\mathrm{LU}$ & 60.34 & 66.09 & 67.41 & 60.29 & 61.45 & 56.15 & 66.78 & 70.29 & 76.39 & 75.13 & 1.24 \\
\hline Sweden & SE & 58.81 & 64.61 & 68.28 & 73.56 & 78.22 & 78.11 & 81.02 & 72.77 & 77.88 & 84.19 & 1.43 \\
\hline Austria & AT & 51.23 & 48.09 & 51.05 & 51.29 & 52.83 & 53.63 & 58.63 & 56.75 & 59.98 & 61.98 & 1.21 \\
\hline Denmark & DK & 49.44 & 72.72 & 78.34 & 80.81 & 82.74 & 85.27 & 84.44 & 88.08 & 88.32 & 89.21 & 1.80 \\
\hline France & FR & 48.10 & 47.34 & 57.26 & 56.83 & 61.44 & 60.21 & 63.77 & 62.80 & 65.86 & 67.92 & 1.41 \\
\hline Germany & $\mathrm{DE}$ & 44.49 & 48.09 & 49.90 & 49.99 & 51.10 & 49.08 & 52.66 & 53.27 & 54.57 & 53.47 & 1.20 \\
\hline United Kingdom & UK & 39.60 & 47.96 & 48.14 & 39.65 & 43.26 & 40.92 & 51.36 & 49.02 & 52.62 & 49.01 & 1.24 \\
\hline Slovakia & SK & 39.55 & 37.63 & 50.48 & 48.23 & 42.40 & 32.72 & 57.05 & 50.72 & 47.94 & 47.48 & 1.20 \\
\hline Estonia & $\mathrm{EE}$ & 37.07 & 46.37 & 50.01 & 53.04 & 54.33 & 48.39 & 50.70 & 81.28 & 76.93 & 77.98 & 2.10 \\
\hline European Union 28 & EU28 & 35.22 & 37.22 & 40.74 & 40.70 & 43.90 & 41.47 & 46.69 & 46.21 & 48.26 & 48.80 & 1.39 \\
\hline Slovenia & SI & 34.62 & 35.48 & 44.34 & 45.64 & 48.05 & 51.54 & 52.94 & 45.21 & 45.36 & 49.86 & 1.44 \\
\hline Ireland & IE & 34.15 & 36.84 & 36.80 & 44.06 & 49.34 & 45.23 & 51.45 & 49.81 & 51.77 & 55.34 & 1.62 \\
\hline Spain & ES & 31.27 & 34.06 & 38.46 & 38.27 & 43.77 & 43.69 & 49.00 & 49.38 & 50.14 & 52.35 & 1.67 \\
\hline Hungary & $\mathrm{HU}$ & 28.13 & 30.27 & 34.32 & 37.65 & 42.28 & 37.15 & 48.72 & 42.21 & 48.21 & 47.13 & 1.68 \\
\hline Belgium & $\mathrm{BE}$ & 26.24 & 40.62 & 45.27 & 47.25 & 49.77 & 49.61 & 55.06 & 52.14 & 54.90 & 55.14 & 2.10 \\
\hline Malta & MT & 25.31 & 33.78 & 37.39 & 37.25 & 40.91 & 31.62 & 40.28 & 41.83 & 43.85 & 45.07 & 1.78 \\
\hline Lithuania & LT & 22.48 & 21.62 & 24.23 & 29.35 & 35.91 & 33.60 & 41.47 & 43.70 & 44.89 & 48.40 & 2.15 \\
\hline Poland & PL & 21.65 & 24.65 & 28.07 & 27.56 & 31.59 & 22.65 & 26.87 & 26.57 & 30.22 & 30.81 & 1.42 \\
\hline Latvia & LV & 20.48 & 29.72 & 39.95 & 41.31 & 47.25 & 35.41 & 53.54 & 52.13 & 69.45 & 68.51 & 3.34 \\
\hline Italy & IT & 19.80 & 20.80 & 22.70 & 22.18 & 19.12 & 20.63 & 22.98 & 23.98 & 24.10 & 24.56 & 1.24 \\
\hline Czech Republic & $\mathrm{CZ}$ & 19.12 & 26.37 & 22.90 & 42.20 & 30.48 & 29.26 & 37.08 & 32.33 & 35.90 & 45.60 & 2.38 \\
\hline Portugal & PT & 18.60 & 21.10 & 26.07 & 36.51 & 38.85 & 37.66 & 41.39 & 43.11 & 44.68 & 45.98 & 2.47 \\
\hline Cyprus & $\mathrm{CY}$ & 17.93 & 24.46 & 25.39 & 29.18 & 29.86 & 30.19 & 41.45 & 33.69 & 38.38 & 42.30 & 2.36 \\
\hline Croatia & HR & 15.55 & 17.05 & 19.42 & 17.40 & 25.70 & 24.85 & 31.94 & 35.07 & 36.18 & 32.20 & 2.07 \\
\hline Greece & EL & 12.72 & 14.40 & 15.78 & 26.83 & 34.27 & 35.59 & 45.12 & 46.40 & 48.89 & 47.35 & 3.72 \\
\hline Bulgaria & BG & 9.97 & 11.44 & 24.24 & 25.43 & 26.64 & 22.57 & 21.02 & 17.84 & 18.60 & 20.67 & 2.07 \\
\hline Romania & RO & 0.00 & 6.96 & 8.31 & 7.22 & 3.77 & 4.93 & 10.19 & 10.77 & 9.07 & 8.73 & \\
\hline
\end{tabular}

Source: According to European Commission, Digital Scoreboard, 2017

The shift to individualized sources of online media may offer governments the biggest opportunities to produce more efficient and effective services and policies, and might represent key factor in the state's response to mounting social and economic challenges, such as aging societies and climate change that are already highlighting the limits of governments' policy capacity (Jones, 2017). Only a well-functioning and efficient public sector is capable of supporting the qualitative development of society, ensuring social and economic equilibrium, and providing life's certainties to citizens (Čepelová, 2014). 


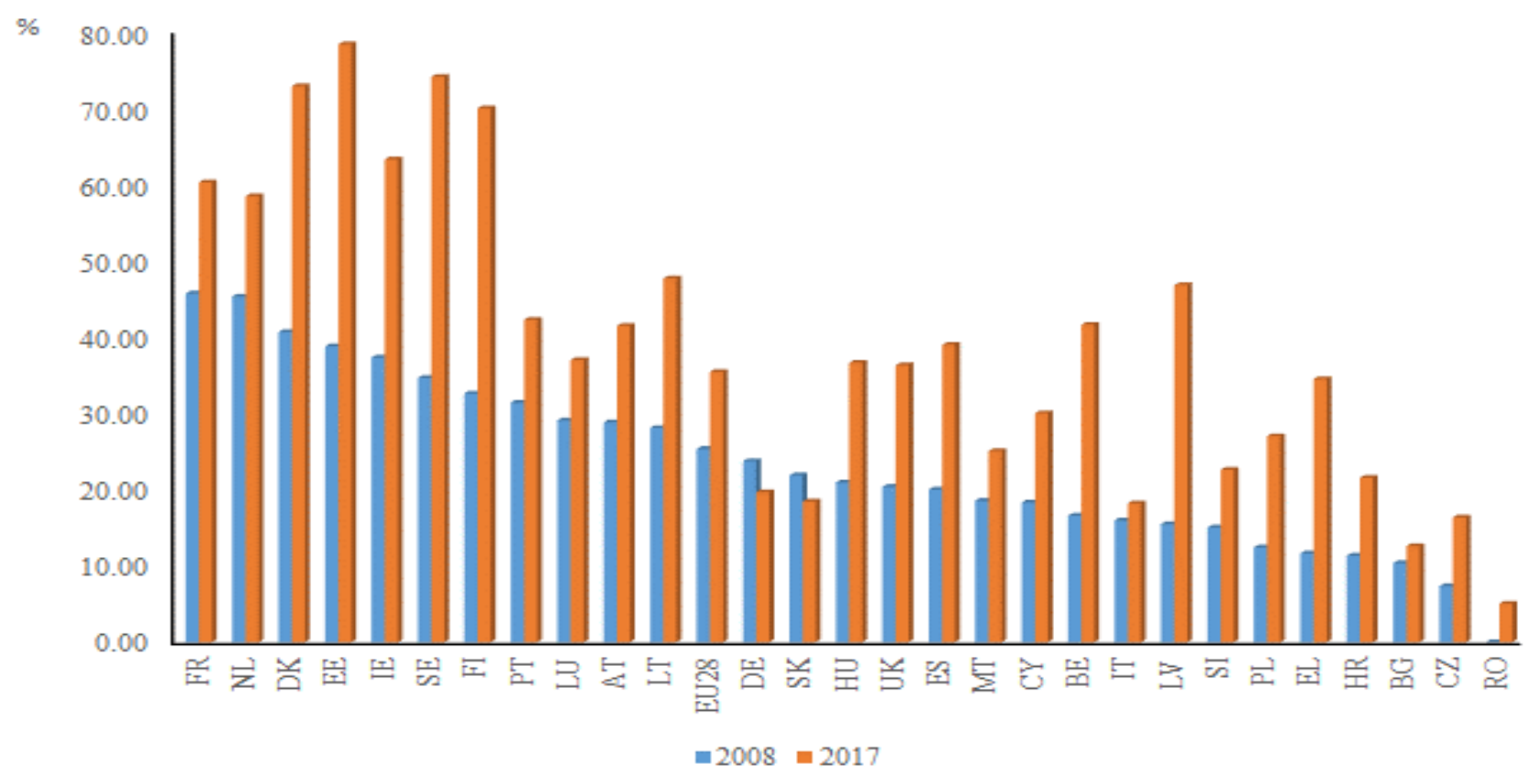

Source: According to European Commission, Digital Scoreboard, 2017

\section{Figure 2. Individuals submitting completed forms to public authorities, over the internet, last} 12 months

The result of the electronization of the public administration is not only the disclosure of information about the individual public administration bodies to the general public but also the possibility for citizens to communicate directly through e - forms with the public administration bodies. This is also confirmed by the results of survey conducted in EU countries which monitoring the number of citizens communicating with public administrations through e-forms. The results of the survey show that, on average, in the EU 28 in 2017 compared to 2008, the number of citizens communicating with the public administration through e - forms increased by $40 \%$. The most significant increase of the number of these citizens are registered in Latvia (more than a 3 - fold increase) and more than a 2- fold increase we see in Poland, Sweden, Finland, Estonia, Belgium, Greece and the Czech Republic (Figure 2, Table 2). The analysis also showed that in Romania, only $5 \%$ of citizens use the option of directly communicating electronically with public administrations. But Urs (2018) note that Romania, as a member of the European Union, is also within the scope of the Europe 2020 strategy involved in the Digital Agenda which aims to is unleash the digital potential and diff use the digital culture widely across the EU. The Romanian government has committed itself that for example, at least $35 \%$ of people use e-government systems; at least $60 \%$ of citizens use the Internet regularly; at least $30 \%$ of citizens make purchases online; what would help public institutions advance the development of a digital society.

The use of such an on - line communication with representatives of the public administration is currently very popular in terms of saving people's time. This communication is not only quicker 
but also more efficient because in the event of any additional information from the citizens, they can react quite quickly and thus accelerate the whole process of the solution.

Table 2. Individuals submitting completed forms to public authorities, over the internet, last 12 months in EU - 28 over the years 2007-2018 (\%)

\begin{tabular}{|c|c|c|c|c|c|c|c|c|c|c|c|c|}
\hline name & code & 2008 & 2009 & 2010 & 2011 & 2012 & 2013 & 2014 & 2015 & 2016 & 2017 & $\begin{array}{c}\text { Index } \\
2008 / 2017\end{array}$ \\
\hline France & FR & 45.70 & 42.20 & 51.49 & 44.69 & 47.85 & 37.76 & & 43.39 & 56.13 & 60.28 & 1.32 \\
\hline Netherlands & NL & 45.30 & 45.73 & 47.06 & 51.83 & 53.65 & 60.05 & 61.10 & 56.09 & 58.18 & 58.46 & 1.29 \\
\hline Denmark & DK & 40.63 & 50.41 & 66.87 & 70.45 & 74.75 & 68.89 & 68.76 & 72.99 & 72.99 & 72.89 & 1.79 \\
\hline Estonia & $\mathrm{EE}$ & 38.78 & 48.63 & 50.85 & 46.85 & 42.30 & 36.70 & 37.62 & 77.64 & 77.64 & 78.38 & 2.02 \\
\hline Ireland & IE & 37.32 & 38.39 & 38.88 & 44.56 & 48.26 & 44.54 & 56.04 & 56.49 & 58.04 & 63.29 & 1.70 \\
\hline Sweden & SE & 34.64 & 39.83 & 39.69 & 44.37 & 48.06 & 48.43 & 53.58 & 48.92 & 50.21 & 74.11 & 2.14 \\
\hline Finland & FI & 32.58 & 39.93 & 44.91 & 44.66 & 49.33 & 48.53 & 60.35 & 62.73 & 63.93 & 69.99 & 2.15 \\
\hline Portugal & PT & 31.39 & 35.19 & 35.64 & 47.96 & 43.12 & 41.59 & 42.75 & 40.78 & 41.17 & 42.26 & 1.35 \\
\hline Luxembourg & LU & 29.06 & 26.56 & 25.34 & 27.63 & 26.70 & 26.59 & 36.57 & 35.68 & 36.17 & 36.98 & 1.27 \\
\hline Austria & AT & 28.80 & 25.85 & 26.99 & 30.57 & 32.11 & 34.11 & 36.18 & 36.66 & 38.25 & 41.48 & 1.44 \\
\hline Lithuania & LT & 28.07 & 25.77 & 27.92 & 37.14 & 42.78 & 39.97 & 42.74 & 42.31 & 38.25 & 47.68 & 1.70 \\
\hline European Union 28 & EU28 & 25.34 & 26.68 & 29.21 & 27.80 & 23.29 & 27.05 & 32.77 & 32.11 & 33.56 & 35.41 & 1.40 \\
\hline Germany & $\mathrm{DE}$ & 23.72 & 26.89 & 27.87 & 18.57 & 17.79 & 16.89 & 18.42 & 19.06 & 18.75 & 19.65 & 0.83 \\
\hline Slovakia & SK & 21.86 & 25.99 & 25.62 & 14.06 & 21.40 & 19.36 & 19.92 & 16.28 & 18.58 & 18.43 & 0.84 \\
\hline Hungary & $\mathrm{HU}$ & 20.92 & 22.24 & 27.03 & 25.34 & 28.40 & 23.83 & 30.85 & 31.59 & 30.24 & 36.62 & 1.75 \\
\hline United Kingdom & UK & 20.36 & 28.07 & 27.05 & 26.95 & 29.37 & 23.79 & 36.60 & 34.40 & 36.07 & 36.29 & 1.78 \\
\hline Spain & ES & 20.02 & 18.14 & 24.54 & 25.01 & 31.12 & 32.00 & 37.06 & 37.66 & 39.69 & 38.97 & 1.95 \\
\hline Malta & MT & 18.53 & 27.32 & 24.09 & 23.36 & 24.64 & 18.39 & 26.53 & 28.47 & 24.47 & 25.04 & 1.35 \\
\hline Cyprus & $\mathrm{CY}$ & 18.30 & 23.45 & 23.69 & 23.36 & 23.82 & 15.36 & 27.73 & 23.66 & 29.06 & 30.00 & 1.64 \\
\hline Belgium & $\mathrm{BE}$ & 16.57 & 21.65 & 28.31 & 31.09 & 35.03 & 38.23 & 42.22 & 39.24 & 39.95 & 41.59 & 2.51 \\
\hline Italy & IT & 15.95 & 14.45 & 13.93 & 13.36 & 14.25 & 17.05 & 17.77 & 17.86 & 16.44 & 18.18 & 1.14 \\
\hline Latvia & LV & 15.47 & 16.95 & 20.86 & 30.26 & 22.28 & 16.53 & 24.66 & 36.40 & 38.15 & 46.81 & 3.03 \\
\hline Slovenia & SI & 15.02 & 17.21 & 16.88 & 20.14 & 21.52 & 28.07 & 29.11 & 24.21 & 22.38 & 22.58 & 1.50 \\
\hline Poland & PL & 12.42 & 13.32 & 15.74 & 13.59 & 16.26 & 17.49 & 21.37 & 22.46 & 25.02 & 26.99 & 2.17 \\
\hline Greece & EL & 11.62 & 13.11 & 14.48 & 23.78 & 32.10 & 32.24 & 37.52 & 37.11 & 37.53 & 34.48 & 2.97 \\
\hline Croatia & HR & 11.33 & 15.86 & 11.61 & 10.45 & 14.16 & 15.21 & 18.27 & 21.34 & 23.13 & 21.55 & 1.90 \\
\hline Bulgaria & BG & 10.35 & 12.09 & 17.95 & 19.80 & 20.56 & 15.08 & 12.56 & 15.09 & 10.48 & 12.58 & 1.22 \\
\hline Czech Republic & $\mathrm{CZ}$ & 7.34 & 9.81 & 8.28 & 44.64 & 17.60 & 9.11 & 13.69 & 12.04 & 14.73 & 16.33 & 2.22 \\
\hline Romania & RO & 0.00 & 9.14 & 10.38 & 7.50 & 7.56 & 3.45 & 5.75 & 7.96 & 5.83 & 5.03 & \\
\hline
\end{tabular}

Source: According to European Commission, Digital Scoreboard, 2017

One of the tool of good governance is the concept also the so-called Smart Administration. Ochrana, Púček, (2011) note that it represents a way of governance that relies on the rigorous application of existing laws, the effective exercise of the powers of the public administration and the effective communication of all the actors involved. To implement this concept into practice, it is necessary to select and implement the right (most needed and most important) investments, activities, measures and legislation. These must be properly implemented, which means measuring the achieved goals while at the same time knowing how to communicate properly with the public. Meijer, Bolívar (2015) note that in the literature (table 3) that they analyzed on smart cities, they found three different types of ideal-typical definitions: smart cities as cities using smart technologies (technological focus), smart cities as cities with smart people (human resource focus) and smart cities as cities with smart collaboration (governance focus). In the group of publications with a technological focus, authors emphasize the possibilities that new technologies offer to 
strengthen the urban system. The publications with a human resource focus do not ignore technology but focus on smart people as being central to the operation of smart cities. The publications with a governance focus highlight the interactions between various stakeholders in the city in their definition as the defining feature of a smart city.

Table 3. Definitions of Smart City

\begin{tabular}{|c|c|c|}
\hline Smart city as.... & Focus & Number of papers \\
\hline Smart technology in the city & Technology & 12 \\
\hline Smart people in the city & Human resources & 4 \\
\hline Smart collaboration in the city & Governance & 6 \\
\hline
\end{tabular}

Source: According to Meijer, Bolívar, 2015

In the face of globalization and growing international competition, the new public and private sector cooperation paradigm or public-private partnership (PPP) has proven to be the best vector of a stable country's or region's development (Dmitrieva, Guseva, 2017). The PPP concept is closely linked to another theoretical approach that is used in public administration, and it is public enterprise. Farazmad (1996) note that the concept of public enterprise management is not a new phenomenon. In fact, it has strong historical roots. It was a very well-developed concept of public administration in the Persian Empire. Public enterprise was a key element of the Persian administrative system. Goods and public goods were provided by state-owned enterprises, with most public goods being monopolistic. The management of public enterprise also has strong historical roots in many other countries, eg. Iran - Turkish civilization, the Ottoman Empire, which continued in Persian tradition and greatly contributed to the creation of public administration, including public enterprise systems. Japan, India, Australia, France and the Scandinavian countries have a concept of public enterprise management based on the principles of the Persian administration system. The rapid growth rate of public enterprises around the world was recorded in the mid-twentieth century, especially after the Second World War. In developing countries, the largest increase took place in the 1960s and 1970s, a period of state building and nationalization. Osborne, Gaebler (1992) mention that the base of characteristics of the public enterprise is competition in the provision of services by the public administration? possibly public inspection? focuses on output rather than on rules? offers citizens a choice of service? focuses on revenue rather than spending? focuses on prevention rather than on solving the problem? decentralization? use of market mechanisms? use of all sectors of national economy to solve the problem.

\section{Conclusions}

From the analysis of selected indicators has shown that the share of the population aged 1674 , who electronically communicate with individual public administrations, is increasing across all 
EU member states. This increase present $39 \%$ over the analyzed period. At the same time, the share of citizens who use the opportunity to solve their problems with public administrations directly through e - forms grows. Even in this case, the increase in the monitored period was $40 \%$. This increase is mainly related to the introduction of e - Government into everyday public administration practice as well as the self - development of ICT technologies.

All changes, respectively the introduction of new innovative approaches to public administration is therefore being implemented in order to ultimately improve the quality of public administration. Modernization of public administration on the one hand is related to the changes that the client expects (not only the citizens itself but all entities requesting service from public administrations) as the recipient of the service and, on the other hand, public authorities as service providers they expecting a reduction cost of service provision and more effective troubleshooting. Many innovative approaches in public administration have a basis in the business sector. However, when applying them to public administration, an important aspect is not the profit but the satisfaction of the client. However, it is necessary to combine these two views in the end, as a result, public administration would become part of the $3 \mathrm{E}$ (economy, effectiveness, efficiency) approach. Thus, a key factor for the future of effective public governance is strategic management that identifies key factors that could influence decision-making in public administrations in the future. For further research in this area, it would be interesting to identify factors that could influence efficiency of e - government use in public administration and also to monitor the specific services that citizens most often use in electronic communication with subjects of public administrations.

\section{Acknowledgment}

This paper is an output of the science project VEGA No.1/0407/18 "Measuring performance of the local self - government."

\section{References}

Beresecká, J. (2014). Self Management in the Creative Industries. 17th International Colloquium on Regional Sciences, Brno: Masaryk University, p. 270-277.

Bevir, M., Rhoedes, R.A.W., Weller, P. (2003). Tradition and governance. UK: University of Newcastle, p. 30.

Castellanos, CEQ (2017). Governance and Theory of Organizations. Perfiles Latinoamericanos, 25(50): 39-57.

Čepelová, A. (2014). Knowledge Management in Public Administration of the Slovak Republic. International Multidisciplinary Scientific Conferences on Social Sciences and Arts (SGEM 2014), Albena: Bulgarian Acad Sci, p. 209-216. DOI: 10.5593/sgemsocial2014/B21/S4.029

Danshina, Y., Britchenko, I. (2017). Adaptation of Domestic State Governance to International Governance Models. Baltic Journal of Economic Studies, 3(5): 116-124.

Dmitrieva, E., Guseva, M. (2017). Justification of Approach to Classification of Innovations in Public-Private Partnership. Economic Annals-XXI, 163(1-2): 64-70. 
Dudchenko, V., Vitman, K. (2018). Public Administration of Economic Development in the Context of the Institutional Theory. Baltic Journal of Economic Studies, 4(1): 139-147.

Ebbers, W.E., Jansenb, M.G.M., van Deursen, A.J.A.M. (2016). Impact of the Digital Divide on E-Government: Expanding from Channel Choice to Channel Usage. Government Information Quarterly, 33(4): 685-692.

Farazmad, A. (1996). Public Enterprise Management. (International Case Studies), USA: Greenwood Press, p. 301.

Fernandez-Falero, MR., Trabadela-Robles, J., Garces-Botacio, I., Ruano-Lopez, S. (2017). City Councils Online Political Communication through their Websites. Case of Extremadura, Spain. Profesional De La Informacion, 26(3): 404-410. https://doi.org/10.3145/epi.2017.may.06

Hamalová, M., Belajová, A., Gecíková, I., Papcunová, V. (2014). Theory, Management and Organization of Public Administration, Bratislava: Wolters Kluwer, p/ 454.

Hrašková, D. (2011). Management in the Public Administration. [online] [accessed 2018-08-15]. Available from Internet: http://www.poradca.sk/SubPages/OtvorDokument/Clanok.aspx?idclanok=70042

Hudáková, J. (2016). Stock of Foreign Investment and its Impact on the Development of the Regions in the Slovak Republic. International Scientific Conference on Region in the Development of the Society, Brno: Mendel University, p. 315-321.

Jones, P. (2017). The Futures of Canadian Governance: Foresight Competencies for Public Administration in the Digital Era. Canadian Public Administration-Administration Publique Du Canada, 60(4): 657-681. https://doi.org/10.1111/capa.12241

Lacina, K. (2012). Developing Ways of Managing Public Administration from Concept New Public Management to Concept Governance. Veřejná správa, Pardubice: Univerzita Pardubice, p. 27-50.

Laurence E. Lynn, Jr. (2001). Public management. In: Handbook of Public Administration, Sage Publications, Inc.

Meijer, A., Bolívar, M.P.R. (2015). Governing the Smart City: A Review of the Literature on Smart Urban Governance. International Review of Administrative Sciences, 8(2): 392-408. https://doi.org/10.1177/0020852314564308

Moon, MJ. (2002). The Evolution of E-Government among Municipalities: Rhetoric or Reality? Public Administration Review, 62(4): 424-432.

Mura, L., Daňová, M., Vavrek, R., Dubravska, M. (2017). Economic Freedom - Classification of its Level and Impact on the Economic Security. Ad Alta-Journal of Interdisciplinary Research, 7(2): 154-157.

Ochrana, F., Půček, M. (2011). Effective implementation and management of changes in public administration. Smart Administration, Praha: Wolters Kluwer, p. 248.

Országhová, D. (2017). Labour-Force Participation Rate in Context of Demographic Changes in Regions of Slovakia. 20th International Colloquium on Regional Sciences, Brno: Masaryk University, p. 374-380.

Osborne, D., Gaebler, T. (1992). Reinventing Government: How the Entrepreneurial Spirit Is Transforming the Public Sector. USA: Plume, p. 411.

Schick, A. (1999). Opportunity, Strategy, and Tactics in Reforming Public Management. Paper presented at the $O E C D$ Symposium, Government of the Future: Getting from Here to There, September 14 - 15, Paris.

Singh, S., Travica, B. (2018). E-Government Systems in South Africa: An Infoculture Perspective. Electronic Journal of Information Systems in Developing Countries, 84(4): 1-16. https://doi.org/10.1002/isd2.12030

Stasiak-Betlejewska, R., Kováč, M. (2013). Analysis of the Administration Procedure for the Construction Permits. Verejná správa a regionálny rozvoj, IX(2): 111-118.

Staroňová, K. et al. (2010). Innovation in the Public Sector of Slovakia (case studies).Bratislava: Comenius University. p. 178.

Urs, N. (2018). E-Government Development in Romanian Local Municipalities: A Complicated Story of Success and Hardships. Transylvanian Review of Administrative Sciences, 55E: 118-129.

Vanagas, R., Juškys, A. (2017). Management of Conflict of Interest in the Public Sector in Lithuania: Theory and Practice. Contemporary Research on Organization management and Administration, 5(1): 6-21

Výrostová, E. (2017). Commuting to School within Kosice Functional Urban Region. 20th International Colloquium on Regional Sciences, Brno: Masaryk University, p. 335-341.

Wright, G., Nemec, J. (2003). Management of Public Administration. (Theory and Practice). Praha: Ekopress. p. 419. 